\title{
„ante alias venit in mentem [...] Iohanna, serenissi- ma Ierusalem et Sicilie regina" Egy ajánlás tervezett és tényleges címzettje - Johanna királynő és Andrea Acciaiuoli szerepe a De mulieribus clarisban ${ }^{1}$
}

Boccaccio célja a De mulieribus claris megírásával valószínüleg nem csupán az volt, hogy erkölcsi példamutatással szolgáljon kora olvasóközönségének, hanem, ahogyan azt az Ajánlás és a Johanna, nápolyi királynőnek szentelt fejezet (De mulieribus 106) is bizonyítják, az írás egyes fázisaiban saját politikai befolyása növelésének szándéka is vezérelte őt. ${ }^{2} \mathrm{Ez}$ utóbbi cél eléréséhez Boccaccio korának két meghatározó hölgyét választotta, akiktől az irodalmi mü biztosította hírnév fejében a nápolyi udvarban remélt megbízatást. ${ }^{3}$ De mikor és miért éppen rájuk esett a választása?

1362 nyarán, Niccolò Acciaiuoli, ${ }^{4}$ Johanna nápolyi udvarmestere, akivel Boccaccio addigra már több évtizedes ismeretséget ápolt, meghív-

\footnotetext{
${ }^{1}$ A publikáció az MTA-SZTE Antikvitás és Reneszánsz: Források és Recepció Kutatócsoport (TK2016-126) támogatásával jelent meg.

2 Boccaccio politikai nézeteiről és azok kifejtéséről az életművében ld. HANKINS (2019: 3-26).

${ }^{3}$ Zanobi da Strada 1361-ben bekövetkezett halála után megüresedett az általa betöltött apostoli titkári (segretario apostolico) pozíció. Miután Petrarca visszautasította a tisztséget, Niccolò Acciaiuoli Boccacciónak ajánlotta fel, aki a kedvezőtlen firenzei politikai helyzetre és anyagi gondjaira való tekintettel elfogadta azt. FILOSA (2012: 33).

${ }^{4}$ Niccolò Acciaiuoli életéről és politikai szerepéről ld. DBI (1960).
} 
ta őt Nápolyba. ${ }^{5}$ Ez arra ösztönözte Boccacciót, hogy a diplomáciai okokon túl, hálából a meghívásért a nápolyi királyi udvar egy tagjának, Andrea Acciaiuolinak, Niccolò húgának ajánlja híres és hírhedt hölgyek tetteit tartalmazó gyüjteményét, s a majdani vendéglátásért és az érdekében való közbenjárásért cserébe a mű lezárásaként pedig beillessze a Johannáról szóló fejezetet.

Az Ajánlás azonban nem ennyire egyenes és egyértelmű utat vázol fel olvasója előtt. Abban ugyanis a szerző hosszas vívódásának lehetünk tanúi, hiszen saját bevallása szerint eredetileg Johannának ajánlotta volna a munkát. Ez utóbbi szándékától azonban állítása szerint eltántorította attól való félelme, hogy a túlságosan jelentéktelen mű nem méltó az uralkodónőhöz. Így esett választása Andreára, ${ }^{6}$ akinek, miután kiemelkedő jellemét magasztalja, közbenjárását kéri a könyv nyilvánosság elé tárásában, cserébe korszakokon átívelő hírnevet ajánlva neki. Nyilvánvalóan nem véletlen, hogy Boccaccio a nápolyi udvar hölgyei közül választotta ki azt, akinek a művet ajánlotta: egyfelől ennek révén remélt közbenjárást Johannánál, ám ami a mü későbbi sorsa és utóélete szempontjából még inkább meghatározó volt, az ismertség is ily módon volt biztosítható. Ez utóbbit pedig Andrea révén érhette és érte is el, ugyanis neki köszönhetően a De mulieribus ismertté vált az Anjou-udvarban és ezáltal egész Európában, ahogyan azt a számos kézirat és fordítás is bi-

\footnotetext{
${ }^{5}$ A nápolyi tartózkodás ambivalens tapasztalatokat hozott Boccaccio számára. Niccolò Acciaiuolival való nézeteltéréseit a 13. levélben örökítette meg. A látogatás pozitív hozadéka volt viszont, hogy találkozhatott Mainardo Cavalcantival és eljutott Montecassinóba, ahol a kolostor könyvtárában rátalált Martialis epigrammáira. Vö. FILOSA (2012: 33) és PetOletTi (2006: 185-187).

6 Több szempont is vezérelhette Boccacciót, amikor úgy döntött, Andreának ajánlja a müvet. Ajánlásának címzettje annyiban mutat párhuzamot a De casibus virorum illustriuméval, hogy mindkét esetben közeli ismerősnek szól. Andreát nemcsak hogy korábbról ismerte, de már említést is tett róla az Amorosa visionéban (42, 28). Azonban Andrea mellett egyéb okok is szólnak: szükség volt valakire a nápolyi udvarból, akinek ajánlhatta a müvet, eleget téve egy fontos diplomáciai gesztusnak, miszerint irodalmi müvet ajánl vendéglátóinak; nőket tárgyaló műről lévén szó, Boccaccio kézenfekvőnek érezhette, hogy az ajánlást is egy nőnek fogalmazza meg. Végül pedig Andrea „férfias” neve is erősíthette a szerző meggyőződését választása helyességében. Ezzel kapcsolatban vö. ARMSTRONG (2013: 101).
} 
zonyítja. ${ }^{7}$ Ugyanakkor Andreát választani azért is tünhetett ideálisnak, mert kifinomult irodalmi és stilisztikai érzékkel rendelkezett, ${ }^{8}$ latinul írt és olvasott, így személyében értő olvasóra találhatott Boccaccio. Mindezek következtében tehát Johanna az ajánlás tervezett címzettjéből egy fejezet főszereplőjévé vált és a mü végére került, átadva a helyét az immár politikai és irodalmi szempontból is feddhetetlenebb, tényleges címzettnek.

A két szövegrész fordításának egymás mellé illesztését ezen a helyen tehát olyan irodalmi szempontok indokolták, amelyeknek célja rámutatni arra, hogy a mü egészét tekintve, illetve Boccaccio számára milyen jelentőséggel bírt a két hölgy gyüjteménybe illesztése. ${ }^{9}$ Johanna királynő alakját magyar vonatkozásai oldaláról érinteni így ezen a helyen több szempontból sem lenne releváns. Egyfelől, ha a filológiai szempontot tekintjük és elolvassuk a neki szentelt boccacciói fejezetet, látható, hogy abban nem csupán nem szerepel András herceg meggyilkolásának ténye, de még a neve sem. A szöveg ugyanis nem más, mint a királynő enkomiasztikus magasztalása, egyfajta captatio benevolentiae, amelyben létező (és olykor nem létező) erényei felsorolása, illetve az általa kivételes rátermettséggel uralt területek említése mellett egyáltalán nincs helye negatív, vagy akár csak kétes megítélésü epizódoknak. Mindazt, amit Boccaccio sejteni vél az eseményekről, azt a Buccolicum carmen és a De casibus virorum illustrium allegorikus utalásai tartalmazzák, megerő-

\footnotetext{
7 FILOSA (2012: 36).

${ }^{8}$ FILOSA (2012: 34) egy érdekes epizódra hívja fel a figyelmet, miszerint Andrea Acciaiuoli második férjének is komoly kritikusa volt, ugyanis a férfi petrarcai stílusban írt, megítélése szerint félresikerült szonettjeit titokban Firenzébe küldte, hogy az Arnóba dobassa.

${ }^{9}$ Ahogyan a ZACCARIA (2001: 12-13) által elkülönített szerkesztési fázisok és FILOSA (2012: 34-35) is rámutatnak, Boccacciónak számos, a keresztény erkölcsök előtérbe helyezését és magasztalását célzó változtatást kellett végrehajtania a művön amiatt, hogy Andrea Acciaiuoli és Johanna királynő is bekerültek a gyưjtménybe. Az ötödik fázisban a 31. és az 80. életrajzzal egészítette ki a müvet, illetve moralizáló részekkel gyarapította a 26-27., az 51. és a 77. fejezeteket. A hatodik szerkesztési fázisban pedig pontosította a kronológiai szempont szerinti elrendezést, három új életrajzot (86, 105, 106) illesztett be és megírta a Conclusiót, amely felváltotta az eredetileg a mü végén szereplő De feminis nostri temporis c. részt.
} 
sítve a történtek ezen a helyen való tárgyalásának irrelevanciáját. ${ }^{10}$ Másfelől, ha magát a rejtélyes gyilkosságot tekintjük, történészi szemmel is szinte végtelen olvasat és megoldási lehetőség kínálkozik, amelyeknek még csak a felsorolása is eltérítené az olvasót az eredeti célkitüzéstől, illetve az irodalmi szempont csorbulását eredményezné. ${ }^{11}$

Jóllehet minden kétséget kizáróan nem tárhatók fel sem az irodalmi, sem pedig a történeti okok, amelyek Boccacciót arra indították, hogy e két hölgyet a De mulieribus szereplőinek sorába illessze. Ám szerzőjének dilemmáival együtt keretbe foglalva látható a nyugat-európai irodalom első nőéletrajz-gyűjteményének erkölcsi példamutatásnak szánt, ám mégis politikai-diplomáciai érdekektől vezérelt világa, amelynek ismeretében könnyebben érthetővé válik egyes életrajzok jelenléte és tartalma is a müben.

\section{Felhasznált irodalom}

Armstrong 2013 G. ARMSTRONG, The English Boccaccio. History in Books, Toronto, 2013.

BROWN 2013 V. Brown (ed.), Giovanni Boccaccio: Famous Women, Cambridge (Massachusetts), 2013.

DBI 1960

DBI 2001

AA.VV, Dizionario biografico degli italiani, Roma, 1960. http://www.treccani.it/enciclopedia/niccoloacciaiuoli_(Dizionario-Biografico)/, 2019.09.10.

AA.VV, Dizionario biografico degli italiani, Roma, 2001. http://www.treccani.it/enciclopedia/giovanna-i-d-angio-reginadi-sicilia_\%28Dizionario-Biografico\%29/, 2019. 09. 10

FILOSA 2012

E. FILOSA, Tre studi sul De mulieribus claris, Milano, 2012.

FRANKLIN 2006

M. FRANKLIN, Boccaccio's Heroines. Power and Virtue in Renaissance Society, London and New York, 2006.

HANKINS 2019

J. HANKINS, Boccaccio and the Political Thought of Renaissance Humanism, in: M. Eisner, D. Lummus (eds.), A Boccaccian Renaissance, Notre Dame, 2019, 3-35.

JULIANI 2019

T. J. Juliani, In the Center of the Kaleidoscope: Ovidian Poetic Image and Boccaccio's Self-Representation in De Mulieribus Claris, in: E. Morra (ed.), Building the Canon trough the Classics. Imitation and Variation in Renaissance Italy (1350-1580), Leiden-Boston, 2019, 27-46.

\footnotetext{
${ }^{10}$ A boccacciói interpretációkról András herceg meggyilkolása kapcsán ld. PETE (2018).

${ }^{11}$ Johanna feltételezett szerepéről András herceg meggyilkolásában, valamint a nápolyi-magyar kapcsolatokról ld. KRISTÓ szerk. (1994: 482) és DBI (2001).
} 
KIRKHAM 2013 V. KIRKHAM, Chronology of Boccaccio's Life and Works, in: V. Kirkham, M. Sherberg, J. L. Smarr (eds.), Boccaccio: A Critical Guide to the Complete Works, Chicago and London, 2013, xiii-xix.

KRISTÓ 1994 GY. KRISTÓ (szerk.), Korai magyar történeti lexikon: 9-14. század, Budapest, 1994.

PETE 2018

L. PETE, “... de vallibus altis Danubii..." L'assassinio del principe Andrea interpretato dal Boccaccio, Italianistica Debreceniensis, 20 (2018), 29-38.

Petoletti 2006 M. PetOletti, La scoperta del Marziale autografo di Giovanni Boccaccio, Aevum, 80 (2006), 185-187.

RICCI 1985 P.G. RICCI, Le fasi redazionali del De mulieribus claris, in: Studi sulla vita e le opere del Boccaccio, Milano, Napoli, 1985, 125-135.

ZACCARIA 1963 V. ZACCARIA, Le fasi redazionali del De mulieribus claris, Studi sul Boccaccio, 1 (1963), 253-332.

ZACCARIA 1967 V. ZACCARIA (ed.), Giovanni Boccaccio: De mulieribus claris (Tutte le opere di Giovanni Boccaccio X.), Milano, 1967.

ZACCARIA 2001 V. ZACCARIA, Boccaccio narratore, storico, moralista, mitografo, Firenze, 2001. 
IOHANNES BOCCACCIUS DE CERTALDO MULIERI CLARISSIME ANDREE DE ACCiarolis de Florentia Alteville COMitisSe. (DedicA)

Pridie, mulierum egregia, paululum ab inerti vulgo semotus et a ceteris fere solutus curis, in eximiam muliebris sexus laudem ac amicorum solatium, potius quam in magnum rei publice commodum, libellum scripsi.

Verum, dum mecum animo versarem cui nam illum primum transmicterem, ne penes me marceret ocio et ut, alieno fultus favore, securior iret in publicum, adverteremque satis non principi viro, sed potius, cum de mulieribus loqueretur, alicui insigni femine destinandum fore, exquirenti digniorem, ante alias venit in mentem ytalicum iubar illud prefulgidum ac singularis, non tantum feminarum, sed regum gloria, Iohanna, serenissima Ierusalem et Sicilie regina. Cuius pensatis, tam inclite prosapie et avorum fulgoribus, quam novis a se forti pectore quesitis laudibus, in desiderium mictendi illum humilem devotumque ante solium sue celsitudinis incidi.

Tandem, quia adeo ingens regius fulgor est et opusculi tenuis et fere semisopita favillula, timens ne a potiori lumine minor omnino fugaretur in tenebras, sensim retraxi consilium; et, nova indagine multis aliis perquisitis, ad extremum ab illustri regina in te votum deflexi meum; nec inmerito. Nam, dum mites ac celebres mores tuos, dum honestatem eximiam, summum matronarum decus, dumque verborum elegantiam mente revolverem, et cum his animi tui generositatem et ingenii vires, quibus longe femineas excedis, adverterem videremque quod sexui $<$ in>firmiori natura detraxerit, id tuo pectori Deus sua liberalitate miris virtutibus superinfuserit atque suppleverit,

\footnotetext{
1 A fordítás alapjául az alábbi kritikai kiadásban megjelent szöveg szolgált: ZACCARIA (1967: 18-23).

2 Boccaccio számos, politikai megbízatásokkal teli év után 1361-ben úgy döntött, hogy firenzei házát mostohafivérére, Iacopóra hagyja és visszavonul Certaldóba. Ekkor készültek el a De mulieribus első vázlatai, a művön pedig 1375-ben bekövetkezett haláláig dolgozott. KIRKHAM (2013: xvii).
} 


\section{A CERTALDÓI GIOVANNI BOCCACCIO A KIVÁLÓ HÖLGYNEK, A FIRENZEI} ANDREA ACCIAIUOLINAK, ALTAVILLA GRÓFNŐJÉNEK (AJÁNLÁS) ${ }^{1}$

Nem sokkal ezelőtt, hölgyek ékessége, a rest tömegtől egy rövid időre elvonulva ${ }^{2}$ és mintegy megszabadulva a többi gondtól, ${ }^{3}$ a női nem rendkívüli dicsőségére írtam egy könyvecskét, ${ }^{4}$ amely inkább szolgál barátaim vigasztalására, mint az állam javára.

Azonban, miközben meghánytam-vetettem magamban, vajon kinek küldjem el először, hogy ne nálam feküdjön mellőzötten és, hogy valaki más jóindulatát élvezve, biztonságosabban a nyilvánosság elé kerüljön, arra a meglátásra jutottam, hogy mivel nőkről szól, inkább egy kivételes hölgynek kell ajánlanom. Miközben az arra legméltóbbat kerestem, mindenkinél előbb jutott eszembe Itáliának az a ragyogó és kivételes csillaga, aki nem csupán a hölgyek, de az uralkodók dicsősége is, a felséges Johanna, Jeruzsálem és Szicília királynője. Miután, egyfelől mérlegeltem híres nemzetségének és őseinek fényét, másfelől erős lelke révén elnyert dicsőségét, elfogott a vágy, hogy ezt az alázattal írt és szerény [könyvet] őfelsége trónja elé vigyem.

Végül, mivel oly nagy a királyi fény, müvecském parazsa viszont egyrészt gyenge, másrészt szinte félig kialudt, attól való félelmemben, hogy a hatalmasabb fény a kisebbet a teljes sötétségbe üzi, lassanként mégis elálltam szándékomtól. És miután további igyekezetem során sok lehetőséget mérlegeltem, végül úgy határoztam, hogy a kiváló királynő helyett téged választalak. Nem érdemtelenül. Ugyanis, amikor elmémben újra felidéztem szelíd és híres jellemed, kivételes tisztességed, a matrónák legnagyobb ékességét, valamint szavaid választékosságát, mindezekkel együtt pedig lelked nemességét és elméd élességét, amelyekkel messze kiemelkedsz a női nem képviselői közül, észrevettem és beláttam, hogy amit a gyengébb nemtől a természet megtagadott, azt Isten a te lelkedben bőkezűen túlárasztotta és megtöltötte csodás erényekkel.

\footnotetext{
3 JULIANI (2019: 38) felveti az ovidiusi száműzetéssel való párhuzam lehetőségét, ám azzal a különbséggel, hogy míg Ovidius nem önként ment Tomiba, és nem találta meg a lelki nyugalmat, addig Boccaccio világtól való elvonulása teljesen önkéntes, sőt lelki felüdülést is hozott számára.

${ }^{4}$ Allúzió az ovidiusi libellusra. Boccaccio, akárcsak Ovidius az Amoresben és a Tristiában, az ajánlásban, az előszóban és a konklúzióban utal így művére. Ezzel az összevetéssel kapcsolatban ld. JULIANI (2019: 36).
} 
et eo, quo insignita es nomine, designari voluerit - cum andres Greci quod latine dicimus homines nuncupent - te equiparandam probissimis quibuscunque, etiam vetustissimis, arbitratus sum. Et ideo, cum tempestate nostra multis atque splendidis facinoribus agentibus clarissimum vetustatis specimen sis, tanquam benemerito tuo fulgori huius libelli tituli munus adiecisse velim, existimans non minus apud posteros tuo nomini addidisse decoris quam fecerit, olim Montisodorisii et nunc Alteville comitatus, quibus te Fortuna fecit illustrem.

Ad te igitur micto et tuo nomini dedico quod hactenus a me de mulieribus claris scriptum est; precorque, inclita mulier, per sanctum pudicitie nomen, quo inter mortales plurimum emines, grato animo munusculum scolastici hominis suscipias; et, si michi aliquid creditura es, aliquando legas suadeo; suis quippe suffragiis tuis blandietur ociis, dum feminea virtute et historiarum lepiditate letaberis. Nec incassum, arbitror, agitabitur lectio si, facinorum preteritarum mulierum emula, egregium animum tuum concitabis in melius. Et esto non nunquam lasciva comperias immixta sacris - quod ut facerem recitandorum coegit oportunitas - ne omiseris vel horrescas; quin imo perseverans, uti viridarium intrans, eburneas manus, semotis spinarum aculeis, extendis in florem, sic, obscenis sepositis, collige laudanda; et quotiens in gentili muliere quid dignum, christianam religionem professa legeris, quod in te fore non senseris, ruborem mentis excita et te ipsam redargue quod, Christi delinita crismate, honestate aut pudicitia vel virtute supereris ab extera; et, provocato in vires ingenio, quo plurimum vales, non solum ne supereris patiare, sed ut superes quascunque egregia virtute coneris;

\footnotetext{
${ }^{5}$ Andrea Acciaiuoli második házasságkötésének éve ZACCARIA (1967: 481) szerint nem rekonstruálható teljes bizonysággal, ám Boccaccio szóhasználata (et nunc) alapján azt feltételezi, hogy 1362-ben került rá sor, nem sokkal az ajánlás megszületése után.

${ }^{6}$ Utalás arra, hogy Andrea kétszer házasodott. Első férje, Carlo Ortus, aki révén Monte Odorisio grófnője volt, 1346-ban halt meg. Második férje, II. Bartolomeo da Capua pedig Altavilla grófja volt. Ennél több említést nem tartalmaz a szöveg a két férjről, sem az újbóli házasságkötés tényéről, hiszen az ellentmondana a mű által közvetített boccacciói elképzeléseknek, miszerint a nőknek férjük halála után tisztes özvegységben kell élniük. BROWN (2003: xiv) a De mulieribus angol fordításához írt bevezetőben felveti annak lehetőségét, hogy Boccaccio azt remélte, Andrea nem fogja sokat forgatni a müvet, így nem figyel fel arra, hogy abban mennyire nagy hangsúlyt kap a tisztes özvegység megőrzése, ám ez kevésbé valószínüsíthető, hiszen egy el nem olvasott mü terjesztésébe és népszerüsítésébe aligha kezdett volna bele.
} 
És úgy gondolom, a névvel, amely ékesít (mivel, amit latinul hominesnek mondunk, azt a görögök andresnek), azt akarta jelezni, hogy téged a legkiválóbbakhoz, méghozzá a legősibbekhez kell hasonlítani. És mivel korunkban sok és ragyogó tetteddel a régi idők igen ékes példája vagy, jól megérdemelt fényedhez hozzá szeretném tenni e könyvecske dicsőségének ajándékát. Úgy gondolom ugyanis, hogy az utódok körében nem kisebb dicsőséggel ruházza fel neved, mint amilyennel egykor Monteodorisio, most pedig Altavilla grófsága, ${ }^{5}$ amelyek révén a sors híressé tett téged. ${ }^{6}$

Neked küldöm tehát és a te nevednek ajánlom azt, amit ezidáig7 a híres hölgyekről írtam, és az erkölcsösség szent nevére, amellyel a halandók között leginkább kiemelkedsz, kérlek téged, hírneves hölgy, hogy hálás lélekkel fogadd egy tudósember müvecskéjét, és ha megbízol bennem, azt javaslom, hogy néha-néha olvasd el! Nyugalmas óráidban ugyanis kedvedre van ítéleteivel, mialatt örömödet leled majd az asszonyi erényben és a történetek kellemességében. Úgy vélem, nem lesz hiábavaló az olvasás, ha versenyre kelve a régi korok asszonyainak tetteivel, nagyszerü lelkedet a jobb dolgok felé fordítod. Néha, a szentek közé keveredve találni fogsz pajzán dolgokat, lévén, hogy az elbeszélendő dolgok erre kényszerítettek: ne hagyj fel az olvasással vagy riadj vissza, épp ellenkezőleg, állhatatosan kitartva gyüjtsd a dicséretre méltó dolgokat, félretéve az erkölcsteleneket épp úgy, mint mikor egy díszkertbe lépsz, és elefántcsontszínú kezed csak azután nyújtod a virág felé, miután eltávolítottad a hegyes tüskéket. És valahányszor egy pogány nő esetében valami méltó dolgot olvasol majd, amelyről nem érzed úgy, hogy megvan benned, te, aki a keresztény vallást gyakorlod, támadjon benned szégyenérzet és vádold meg önmagad, amiért Krisztus szent olajával felkent létedre felülmúlt téged erkölcsiségben, szemérmességben vagy erényben egy pogány hölgy. Erős lelkületed folytán, amely már így is kiválóvá tett, ne csupán azt ne türd el, hogy felülmúljanak, hanem arra is törekedj, hogy mások fölé emelkedj rendkívüli erényeddel!

\footnotetext{
7 Ezzel Boccaccio is megerősíti, hogy a mű nem kifejezetten a nápolyi látogatás alkalmából íródott, hanem bizonyos részei azt megelőzően születtek.
} 
ut, uti corpore leta iuventute ac florida venustate conspicua es, sic pre ceteris, non tantum coevis tuis, sed priscis etiam, animi integritate prestantior fias: memor non pigmentis - ut plereque facitis mulieres - decoranda formositas est, sed exornanda honestate sanctitate et primis operibus; ut, dum eidem qui tribuit gratam feceris, non solum hac in peritura mortalitate inter fulgidas una sis, sed ab eodem gratiarum Largitore, hominem exuens, in claritatem suscipiaris perpetuam.

Preterea si dignum duxeris, mulierum prestantissima, eidem procedendi in medium audaciam prebeas. Ibit quidem, ut reor, tuo emissus auspicio, ab insultibus malignantium tutus; nomenque tuum, cum ceteris illustrium mulierum, per ora virum splendidum deferet, teque tuis cum meritis - cum minime possis ubique efferri presentia - presentibus cognitam faciet, et posteritati servabit eternam. Vale. 
Mivel boldog ifjúságod és viruló szépséged okán külsőleg szemrevaló vagy, hogy lelked feddhetetlenségében így mindenkit megelőzve ne csupán a kortársaidnál, hanem a régieknél is kiválóbb légy, emlékezz arra, hogy nem festékkel kell ékesíteni a szépséget, ahogy ti, nők a legtöbben teszitek, hanem tisztességgel, erkölcsi tisztasággal és kiváló tettekkel. Így, miközben kedvére teszel annak, aki megajándékozott vele [a szépséggel] a tovaillanó halandóságban, nem csupán egyedüliként tündökölsz a ragyogó nők között, hanem ugyanannak a kellemnek az Adományozója révén, az emberi léttől megfosztva befogadást nyersz majd az örök világosságba.

Továbbá, ha méltónak tartod majd [könyvecskémet], asszonyok legkiválóbbika, adj neki bátorságot, hogy a közönség elé lépjen! Úgy vélem, odakerül majd a te védelmed alatt útjára bocsátva, védve a rosszakarók gúnyolódásaitól, és más kiváló hölgyekéivel együtt el fogja juttatni a te dicső neved a férfiak ajkára. ${ }^{8}$ És miközben téged érdemeiddel együtt ismertté tesz kortársaid körében, mivel aligha tudsz mindenütt jelen lenni, meg fogja őrizni örökkévalónak [hírneved] az utókor számára is. Isten veled!

${ }^{8}$ Az enniusi szöveghelyet (volito vivos per ora virum) Cicerótól idézve (Tusc. $\left.1,15,34\right)$ illesztette be Boccaccio. 


\section{DE IOHANNA IERUSALEM ET SYCILIE REGINA.}

Iohanna Ierusalem et Sycilie regina preter ceteras mulieres origine potentia et moribus evo nostro illustris est femina. De qua, ni videretur omisisse odium, satius erat tacuisse quam scripsisse pauca.

Fuit ergo hec serenissimi principis Karoli Calabrie ducis incliti et primogeniti celebris memorie Roberti, Ierusalem et Sycilie regis, ac Marie, Phylippi regis Francorum sororis, filia prima. Cuius parentum, si velimus avos proavosque in finem usque exquirere, non subsistemus antequam per innumeros ascendentes reges in Dardanum, primum Ylionis auctorem, venerimus, cuius patrem Iovem dixere veteres. Ex qua tam antiqua tanque generosa prosapia tot hinc inde preclari manavere principes ut nullus christianorum regum sit qui huic non veniat consanguineus vel affinis; et sic nulla diebus patrum nostrorum nec nostris orbe effulsit nobilior. Hec etiam, Karolo patre, ea adhuc infantula, immatura morte subtracto, cum nulla esset Roberto avo melioris sexus proles altera, iure factum est, eo etiam sic mandante, ut eidem morienti superstes regnorum efficeretur heres. Nec equidem ultra torridam zonam aut inter Sauromatas sub glaciali polo illi pregrandis cessit hereditas, quin imo inter Adriaticum et Tyrrenum mare ab Umbria et Piceno ac veteri Volscorum patria in syculum usque fretum sub miti celo;

9 A fordítás alapjául az alábbi kritikai kiadásban megjelent szöveg szolgált: ZACCARIA (1967: 442-449).

${ }^{10}$ A Johannáról szóló fejezet ZACCARIA (2011: 12) és RICCI (1985: 125-135) álláspontja szerint is 1362 júniusában került a De mulieribusba, azt követően, hogy Boccaccio meghívást kapott Niccolò Acciaiuoli, a királynő udvarmestere révén Nápolyba. ZACCARIA (2011: 12-13) a meghívója húgának, Andrea Acciaiuolinak szóló ajánlást az általa elkülönített kilenc közül a negyedik, Johanna életrajzának beillesztését pedig a hatodik szerkesztési fázisra teszi, ám a kritikai kiadáshoz írt előszóban még nem különíti el élesen a két rész mübe illesztését. Vö. ZACCARIA (1967: 7) és ZACCARIA (1963: 289). Ez utóbbi meggyőződést követi FRANKLIN (2006: 23-24), aki egyazon szerkesztési fázisra teszi az ajánlás és a Johanna-életrajz keletkezését.

11 Serv. In Aeneida 1, 235 (ZACCARIA [1967: 556]). 


\section{JOHANNÁRÓL, JERUZSÁLEM ÉS SZICÍLIA KIRÁLYNŐJÉRŐL ${ }^{9}$}

Johanna, Jeruzsálem és Szicília királynője kiváló asszony, akit korunkban származása, hatalma és erkölcsei számos nő fölé emelnek. Ha mellőzése nem tűnne az ellenszenv jelének, előnyösebb lett volna inkább hallgatni, mint keveset írni róla. ${ }^{10}$

Ő tehát elsőszülött lánya volt a felséges Károly hercegnek, Calabria dicső fejedelmének, - aki a nagyhírű Róbertnek, Jeruzsálem és Szicília királyának elsőszülött fia volt, - valamint Máriának, Fülöp francia király nővérének. Ha szüleinek őseit egészen a kezdetekig visszanyúlva akarnánk felkutatni, nem kellene megállnunk addig, amíg számos királyi felmenője között el nem jutunk Dardanoszig, Trója alapítójáig, akinek apjaként a régiek Iuppitert tartják számon. ${ }^{11}$ Ebből az oly ősi és nemes nemzetségből egyik és másik részről is annyi dicső fejedelem származott, hogy nincs olyan keresztény király, aki ne lenne egy vérből való vagy rokon vele. Így napjainkban, sőt még atyáink korában sem tündökölt ennél nemesebben egyetlen nemzetség sem. Johanna pedig még gyermekként, miután apját, Károlyt a korai halál elragadta, minthogy nagyapjának, Róbertnek egyszülött fián kívül az erősebbik nemhez tartozó egyetlen utóda sem volt, a jog értelmében a haldokló utódaként a királyság örököse lett. ${ }^{12}$ És rá nem a perzselő vidéken túli vagy a jéggel borított sark alatti, a szarmaták között elterülő hatalmas örökség szállt, hanem épp ellenkezőleg egy, az Adriai-és a Tirrén-tenger között fekvő, Umbriától és Picenótól, valamint a volscusok ősi hazájától ${ }^{13}$ egészen a szicíliai tengerszorosig érő, enyhe ég alatt fekvő terület.

\footnotetext{
${ }_{12}$ I. Anjou Károly calabriai fejedelem 1328-ban halt meg. A trónon második feleségétől, Valois Máriától sziiletett lánya, Johanna követte, aki apja révén a Jeruzsálem és Szicília királynője címet nyerte el.

${ }^{13}$ Italicus nép, amely a mai Lazio és Molise déli, valamint Campania északi részét lakta. quos inter fines eius parent imperio Campani veteres, Lucani Bruttii Sallentini Calabri Daunique et Vestales ac Samnii Peligni Marsique et alii
} 
plures, ut maiora sinam, ut puta ierosolimitanum regnum, Sycilie insulam et in Cisalpina Gallia Pedimontis territorium, que illi ab usurpantium quorundam occupantur iniuria; sic et qui septimanam provinciam inter narbonensem Galliam Rhodanum Alpesque incolunt et Focalcherii comitatum, suis eque iussis parent eamque sibi fatentur dominam et reginam.

$\mathrm{O}$ quot his in regionibus civitates inclite, quot insignia oppida, quot maris sinus et refugia nautarum, quot navalia, quot lacus, quot medici fontes, quot silve nemora saltus amenique recessus et pinguia arva! Necnon quot numerosi populi, quot ingentes sunt proceres! Quam grandis insuper opulentia et rerum omnium, ad victum spectantium, copia, equidem non esset explicare facile.

Quod cum permaximum sit dominium nec id sit a mulieribus possideri consuetum, non minus miraculi quam claritatis affert, si satis inspicimus. Et, quod longe mirabilius est, sufficit illi ad imperium animus: tam perlucidam adhuc avorum indolem servat. Ea enim, postquam regio dyademate insignita est, virtute insurgens valida, adeo purgavit, nedum civitates et domestica loca, verum Alpes, saltus devios, nemora et ferarum lustra scelesta hominum manu, ut aufugeret omnis terrefacta aut se celsis clauderet arcibus; quos, agmine armatorum emisso sub egregio duce, non ante locorum talium obsidionem solveret, quam, captis munitionibus, infandos homines affecisset supplicio, quod precedentium regum aliquis aut noluit aut fecisse nequivit;

${ }^{14}$ Lucania tartományának lakói, amely a mai Calabria területén található. Északon Samniummal és Campaniával, keleten Apuliával, dél-nyugaton pedig Bruttiumal volt határos.

${ }^{15}$ A mai Calabria tartomány területén elhelyezkedő Bruttium régió lakói.

16 A mai Észak-Puglia területének lakói.

17 Italicus nép, a mai Pescara és L'Aquila területének lakói.

${ }^{18}$ Samnium tartomány lakói, amelyet északról Latium, délről Lucania, nyugatról Campania, keletről pedig Apulia határolt.

${ }^{19}$ A mai Abruzzo területén, a Valle Peligna környékén élt italicus nép.

${ }^{20}$ Italicus nép, a mai Abruzzo területét lakták, Fucino és az azonos nevű tó környékén.

Ennek a birodalomnak a határain belül engedelmeskednek hatalmának az ősi campaniaiak, a lucaniaiak, ${ }^{14}$ a bruttiumiak, ${ }^{15}$ a salentinumiak, a 
calabriaiak, a daunusiak, ${ }^{16}$ a vestinumiak, ${ }^{17}$ a samniumiak, ${ }^{18}$ a pelignumiak, ${ }^{19}$ a marsusok ${ }^{20}$ és még mások is, hogy a nagyobbakat ne is említsem, mint például a jeruzsálemi királyság, Szicília szigete és az Alpokon inneni Galliában ${ }^{21}$ Piemont vidéke. Ezeket a területeket manapság különböző jogtalan trónbitorlók foglalják el tőle. Hasonlóképpen Johanna parancsainak engedelmeskednek és őt vallják úrnőjüknek és királynőjüknek azok, akik a septimana provinciát ${ }^{22}$ lakják a narbói Gallia, a Rhône és az Alpok között, valamint a folcalquieri grófságot.

Ó, mennyi híres állam található ezeken a vidékeken, mennyi kiváló város, mennyi tengeröböl és mennyi menedék a hajósoknak, mennyi kikötő, mennyi tó, mennyi gyógyító forrás, mennyi erdő, berek, hegyi legelő, kies zug és termékeny mező! És valóban, mennyi népes tartomány, mennyi nagyszerű előkelőség! Még elmondani is nehéz lenne, az életet biztosító minden dolognak mily nagy bősége is lelhető fel itt.

Hölgyek fennhatósága alatt általában nem álló, hatalmas kiterjedésü birodalomról lévén szó, ha alaposan szemügyre vesszük, [Johanna] nem csak hírnévre, de csodálatra is okot szolgáltat. És, ami még inkább csodálatraméltó, hogy lelke, még mindig őrizve ősei ragyogó természetét, uralkodásra termett. Ô ugyanis, miután megkoronázták, kiváló erényeivel nem csak a fent említett államokat és a honi területeket, hanem az Alpokat, a félreeső hegyi legelőket, berkeket és a vadak búvóhelyeit is megtisztította az emberek bünös cselekedeteitől úgy, hogy mindenki halálra rémülve elmenekült, vagy magas váraiba zárkózott. Miután fegyveresek csapatát küldte ellenük, élükön egy kiváló vezérrel, ${ }^{23}$ nem hagyott fel e helyek ostromával, amíg halálbüntetéssel nem sújtotta az erődítményeik elfoglalása után a szóban forgó szörnyű embereket. Ezt a korábbi királyok közül senki nem akarta vagy nem tudta felvállalni.

${ }^{21}$ Gallia Cisalpina egykori római provincia Észak-Itáliában.

22 Tévesen nevezi így Boccaccio, a helyes elnevezés Septimania. Ez az egykori római provincia, Gallia Narbonensis (korábbi nevén Gallia Transalpina, vagyis az Alpokon túli Gallia) nyugati részének, a mai Languedoc és Provance területének felel meg.

${ }^{23}$ Utalás a Galeotto Malatesta vezette, 1362-es hadjáratra, amelynek célja a királyság rendjének és biztonságának helyreállítása volt. E két évig tartó háborúról ld. ZACCARIA (1967: 556).

eoque redegit terras quas possidet, ut non solum inops, sed et opulentus cantando nocte dieque possit quo velit tutus iter arripere; et - quod non 
minus salubre - insignes viros Regnique proceres tanta frenavit modestia et eorum mores solutos retraxit in melius, ut, posita superbia veteri, qui reges olim parvipendebant, hodie faciem irate mulieris horrescant. Est insuper oculata femina tantum, ut fraude potius quam ingenio illam decipere queas. Est et magnifica, regio potius quam femineo more; sic et grata memorque obsequiorum; longanimis est et constans, ut sacrum propositum eius non leviter flectas in vacuum: quod satis monstravere iam dudum in eam fortune sevientis insultus, quibus persepe acri concussa motu et agitata est atque turbine circunducta vario. Nam perpessa est intestina regulorum fratrum discordia et extera bella, non nunquam intra regni gremium debachata, sic et alieno crimine fugam exilium et coniugum austeros mores, livores nobilium, sinistram nec meritam famam, pontificum minas et alia, que omnia forte pertulit pectore; et tandem erecto invictoque omnia superavit animo: edepol grandia, nedum mulieri, sed robusto ac prevalido regi! Est illi preterea spectabile ac letum decus oris, eloquium mite et cunctis grata facundia. Et ut illi regalis et inflexa maiestas est, ubi oportunitas exigit, sic et familiaris humanitas, pietas, mansuetudo atque benignitas, ut non reginam suis dicas esse, sed sotiam. Que maiora petas in prudentissimo rege? Esset necnon, si quis de integritate mentis sue omnia explicare velit, sermo longissimus. Quibus agentibus, ego non solum illam reor egregiam et splendida claritate conspicuam, sed singulare decus ytalicum, nullis hactenus nationibus simile visum. 
Olyanná tette az uralma alatt álló földeket, hogy szegény is, gazdag is dalolva, biztonságban utazhatott éjjel-nappal, ahová csak akart. Továbbá nem kevésbé üdvös dolog, hogy a kiváló férfiúkat, valamint a Királyság előkelőit oly nagy higgadtsággal fékezte meg, és eltévelyedett erkölcseiket jobb irányba fordította, hogy akik egykor a királyokat kevésre becsülték, a régi gőgöt félretéve ma rettegnek a feldühödött asszony láttán. Ezen felül olyannyira éleslátó, hogy inkább csellel, mint ésszel tudod őt rászedni. Továbbá nagyszerü is, inkább a királyok, mint a nők módján. Ily módon hálás és emlékezetébe vési az engedelmességet, megértő és állhatatos, olyannyira, hogy szent ígéretét nem könnyen hiúsítod meg. Ezt már régóta elégszer bizonyították az ellene mesterkedő sors támadásai, amelyek igen gyakran heves indulattal rendítették és gyötörték meg őt, s különféle zavargások sújtották. Ugyanis testvérei, a királyfiak viszálya által szított belső, és a külső ellenségekkel vívott, nemegyszer a királyság szívében tomboló háborúknak volt kitéve. Mások hibájából bátor szívvel viselt el menekülést, száműzetést, házastársai zord jellemét, a nemesek irigységét, a meg nem érdemelt rossz hírnevet, a pápák fenyegetéseit ${ }^{24}$ és más dolgokat is, míg végül nemes és rendíthetetlen lélekkel mindent legyőzött. Istenemre mondom, súlyos dolgok ezek, nemhogy egy nő, még egy keménykezű és igen erős király számára is! Azonkívül arcának szemrevaló és pompás szépsége, kellemes beszéde, ékesszólása mindenki számára megnyerővé teszi. Olyan királyi és hajthatatlan fenségességgel bír, amikor a szükség, a bizalmas emberségesség, a könyörület, a szelídség és a jóság úgy kívánja, hogy nem alattvalói királynőjének, hanem szövetségesének mondanád őt. Miféle nagyobb dolgokat keresnél egy bölcs uralkodóban? Minden bizonnyal igen hos-szan lehetne fejtegetni, ha valaki mindent el szeretne mondani lelkének feddhetetlenségéről. Ezért én azt gondolom, hogy ő nem csupán rendkívüli és fenséges hírneve miatt figyelemre méltó, hanem Itália kivételes ékessége, akihez hasonlót egyetlen nemzet sem látott mostanáig.

\footnotetext{
${ }^{24}$ Johanna és a pápák közötti konfliktusokról ld. KRISTÓ (1994: 482) és DBI (2001).
} 